\title{
Central American Research by the Carnegie Institution
}

A

FEATURE to be noted in the most recent developments of archæological research in the field is an increase in specialisation, and where finan. cial considerations will permit, the supplementing of the purely archæological work by research in other branches of science which can be made to assist in the interpretation of archæological results in their bearing on the general problem of the history of man and the development of his culture, whether considered regionally or in its broader aspect. Thus Dr. A. V. Kidder, in his report as chairman of the Historical Section of the Carnegie Institution of Washington (Year Book No. 31), remarks : "It is difficult to escape the conviction that only by coordinated research involving the cooperation of all the disciplines devoted to the study of man and the collateral support of many biological and physical sciences can we attain understanding of any given episode in human history."

It is on these broad lines that the Carnegie Institution is now promoting the study of the archæology of Central America. Investigations which were undertaken originally as a study of the archæology only of the Mayas of Yucatan, have been expanded to embrace, in addition, on an ordered scheme, the geology, geography and climatology of the area, the physical characters of the inhabitants, their physiological characters and liability to disease, their ethnological affinities, their languages and their mode of life and culture.

At Chichen Itzá, the principal zone of interest of the Institution in Yucatan, Dr. S. P. Morley was engaged in the examination of a building known locally as the 'Mercado', although there is no reason to think that its original use was that of a marketplace. It was probably a purely ceremonial building. It consists of a single vaulted chamber, no less than $250 \mathrm{ft}$. long, in which the architect had given full play to technically daring and bold ideas. Thus the vault is $15 \mathrm{ft}$. wide, the broadest span yet recorded for the Maya area. The building displayed the weakness of all other Maya buildings in placing too great reliance upon columnar beams of wood to carry the huge weight of the stone superstructure. The roof crashed even before the abandonment of the city ; but its fall preserved intact a remarkable altar on which was sculptured in relief and brilliantly painted a procession of elaborately costumed captives, marching towards a centrally enthroned figure.

A second major undertaking at Chichen Itzá was the exploration of a building known as the 'Monjas' by Mr. John S. Bolles-a problem of considerable complexity, owing to the fact that a building, originally small, had been continually enlarged by alterations and additions until it became a veritable puzzle in massive masonry. Even on a superficial examination it showed five distinct periods of architectural modification.

From Chichen Itzá an expedition was sent to investigate the newly discovered site of Calakmul in the archæologically unknown region of south central Campeche. Two weeks were spent there. The site proved to be that of a very extensive Old Empire city, remarkable for the unprecedented number of its monuments. The dates of nearly fifty were deciphered, ranging from A.D. 364 until A.D. 550. It was evidently colonised from Peten. Its situation midway between Peten and northern Yucatan gives it great archæological importance.

Next to Chichen Itzá, the Institution's most important archæological centre in the Maya field is Uaxactun, an OId Empire city in Northern Peten, Guatemala, where work has been carried on since 1924. It was the oldest and longest-inhabited centre of Maya culture. Stratified deposits have been uncovered going back far beyond the first stone-carved records. Here, in what is known as the $A$ group of buildings, a palace was excavated by Mr. Ledyard Smith. This is a type of building in the Old Empire of which very little is known. It was found to consist of four courts surrounded by cell-like structures. The greatest height of the building as it now stands is nearly $50 \mathrm{ft}$. The north court and main court were excavated and were found to be on different levels and connected by stairways. A number of pyramids were also examined, and were found to contain burial vaults which yielded much valuable pottery.

Advantage was taken of the temporary residence of Dr. S. K. Lothrop in Guatemala to engage him in carrying out a preliminary archæological investigation of the Highlands of that area.

In the collateral studies, to which reference is made in the beginning of the report, Guatemala was on this occasion made the principal centre of activity. Geographical reconnaissances were made by Dr. Wallace W. Atwood, president of Clark University, and Dr. Rollin S. Atwood of the University of Florida, the former undertaking the definition of the physiographic provinces of the Highlands, with special reference to Lake Atitlan and adjoining territory ; while Dr. Rollin Atwood made a detailed geographical survey of the region of Chichicastenango.

A medical expedition worked in Yucatan under Dr. George M. Saunders, collecting information upon the various forms of malaria and amœbic dysentery. The prevalence of three types of malaria was demonstrated, as well as an infestation with the amœbæ causing dysentery. The medical expedition to Guatemala under Dr. George G. Shattuck had as its objective a general knowledge of the diseases prevalent in the Highland area and the collection of material for comparison with the low-lying Yucatan Peninsula, especially with reference to the Indian population. In Guatemala, as in Yucatan, the Indians showed an extraordinary resistance to the virus of syphilis.

At Chichen Itzá, Dr. Steggerda made a study of the amount and character of the food of the modern Maya and continued his study of their anthropometry, more especially with respect to growth and genetic study. Dr. Davenport also made an inspection with the view of gauging the possibilities of Yucatan as a field for genetic study.

In the ethnological field Dr. and Mrs. Asael Hansen made a study of the barrio of Santa Ana, a part of Merida which has recently undergone great changes towards urbanisation. In linguistics the work was confined to the study of material collected in previous seasons.

Notwithstanding these varied activities, Dr. Kidder notes a number of further problems in topography, geology and climatology which are especially urgent; while in biology, he says, the field "has hardly been scratched". 